\title{
Management of bladder cancer and urinary tract reconstruction
}

\author{
Dedicated to the memory of John P. Stein, 14 June 1962-11 April 2008
}

\author{
Donald G. Skinner
}

Published online: 13 December 2008

(C) Springer-Verlag 2008

The introduction to this issue of the World Journal of Urology is one I never thought I would have to write but I am honored to be asked to write a few words to help celebrate and honor the life of Dr. John P. Stein who passed away suddenly and tragically on 11 April 2008 at the young age of 45 years while attending the annual meeting of the American Association of Genitourinary Surgeons in Naples, Florida.

John was born on 14 June 1962 in San Francisco and grew up in Walnut Creek, California. He received his Bachelor's degree from the University of Notre Dame in 1984 and his MD Degree from Loyola Stritch School of Medicine in 1989. While at Loyola he became interested in urology under the mentorship of Dr. Robert Flanigan. I first met John as a Loyola medical student in 1988-initially to do a senior elective and subsequently to interview for our program.

John was not first in his class academically nor an AOA at Loyola but there was something special that immediately attracted me to him - a very special spirit and work ethic like no one else.

He was a "domer," and in those days "domers" felt they ruled the world! Two of his close friends from Notre Dame preceded him in our residency, John Freeman and David Esrig, both of whom emboldened the spirit and competitiveness of Notre Dame-at John's final interview we talked sports and his fourth year rotation demonstrated the incredible work ethic, commitment and attention to details

D. G. Skinner $(\bowtie)$

Department of Urology, USC, Norris Cancer Center,

Keck School of Medicine, 1441 Eastlake Ave,

Suite 7416, Los Angeles, CA 90089, USA

e-mail:vanhecke_w@ccnt.hsc.usc.edu that turned out to be the hallmark of his career. He was the favorite of all of the faculty and we convinced him to come to USC as our \#1 draft choice-as I always reminded John you have to move up in life-Notre Dame was a good place to start but USC was the next great step ahead in life!

John was smart-he convinced Randi to leave Chicago for Los Angeles where he shared her with me as a scrub nurse and then Randi became our enterostomal therapist and John was wise and lucky as he married Randi in 1990 — and together they were blessed with four wonderful children.

Simply stated, John Stein turned out to be one of the best residents I ever trained, then an outstanding fellow and I convinced him to stay as a faculty member whose development and accomplishments have been so great that the week of his death he would have been named as my successor as Chairman of our Department of Urology.

John was incredibly productive academically authoring more than 150 articles in peer review journals. Early in his career he focused on the molecular biology of bladder cancer. He collaborated with Peter Jones and Richard Cote and other colleagues to publish a series of landmark articles that demonstrated that deletion or alterations in certain tumor suppressor genes such as $\mathrm{p} 53, \mathrm{p} 21$, and RB could identify patients with invasive bladder cancer likely to progress following cystectomy.

Together John and I demonstrated the importance of a thorough and extended lymph node dissection in the surgical treatment of bladder cancer and John was the first to show the concept that lymph node density correlated better to prognosis than the number of positive nodes.

John was committed to improving the quality of life of his patients. Together we worked on developing better techniques for reconstructing the bladder in patients who lost the organ to cancer. He developed the T-pouch technique 
for orthotopic neobladder reconstruction and determined that the female urethra could usually be spared making that reconstruction possible in women beginning in 1990. This revolutionized bladder reconstruction in women and forever changed the practice of urology.

John received many accolades and awards for his work. In 2003 he received the Young Investigator Award from the Society of Urologic Oncology. In 2005 he was elected into membership of the American Association of Genitourinary Surgeons.

Finally, the last word to define John was as a visionary. I wish you could have seen his presentation to the Dean regarding his vision of the future of urology at USC-he knew were we needed to go, how to improve a great department, yet maintain what he helped establish. Now how tragic it is that John will not be able to implement his plan as my successor.
I have always considered John Stein someone special. He was an extension of my own hands, a son and member of my family - watching the events that transpired early on 11 April and concluded just $20 \mathrm{~h}$ later were the most horrific $20 \mathrm{~h}$ of my life. Why this could happen is impossible to explain and even harder to accept - the best of modern medicine is at times so inadequate and the toxic shock syndrome or idiopathic capillary leak syndrome to which John succumbed remains the greatest mystery and unknown in the field of Infectious Disease. Only God knows. But how lucky we have all been to have had John Stein with us and part of our lives and part of the great field of urology. His spirit, his vision, and all he stood for will live on in all of us.

Conflicts of interest statement There is no conflict of interest. 